\title{
Local Content Curriculum and Standardized National Examination in Indonesia
}

\author{
Fadlia*, Rahmiati, Surya Asra, Teuku Mahatir \\ English Education Department \\ Universitas Samudra \\ Langsa, Indonesia \\ *fadlia@unsam.ac.id
}

\begin{abstract}
This article explores the impact of national versus state initiatives in curriculum. In Indonesian context, the notion of local context curriculum and standardized national examination in Indonesia is being debated. The Local Curriculum Content and the national examination is not in line as a studied content and a given test. The content analysis is used to elaborate the phenomenon of what has been written on academic literature on the notion of national and state curriculum. The discussion concluded that the intention of opening the educational democracy opportunity to lower-level institutions by imposing the Local Curriculum Content could not be used effectively if the government of Indonesia does not support its implementation holistically. The gap between the Local Curriculum Content and the national exit examination still exists. Students still feel fearful that they will jeopardize their future by scoring one point less than the required minimum threshold in national exit examination. Therefore, Indonesia government needs to reconsider for determining students' graduation based on national standardized testing and give more opportunity for state government to apply the Local Curriculum Content.
\end{abstract}

Keywords-local content curriculum, standardized examinantion, national examinantion

\section{INTRODUCTION}

As school systems around the world seek to improve their outcomes and practices, much attention has been focused on devolving educational authorities to the lower level. In 2000, the Indonesian government began to decentralize the governance of its primary and secondary education system as part of broader changes designed to improve education by shifting responsibilities to district and local control. Under the new system, schools were given authority to manage their operations independently according to student needs and were asked to engage the local community to improve the quality of education. This decentralized form includes Local Content Curriculum (LCC) as one of the reforms. This policy required all twenty percent of the elementary and junior secondary schools' curriculum to be locally designed [1].

However, the reforms in national standardized testing do not support the spirit of devolving authority to local level.
National Standardized Exam, in Indonesian named Ujian Nasional (UN), still determines the graduation of students in lower and upper secondary school. The implementation and misguidance LCC and UN have been viewed as two contradictory policies in Indonesia. Further, this study will delineate UN as the national curriculum, which will be contrasted on its implementation with LCC as the state initiative curriculum. Therefore, this study will also explore various impacts of the current UN and LCC on some aspects of secondary education.

This study needs to be considered to create local curriculum [1]. Furthermore, the curriculum designed can be implemented in all the elementary and junior secondary schools. There are many studies which has been conducted related to this topic local content curriculum. A study conducted by Bjork in 2004 about the urgency of decentralization is related to local content curriculum notion. On his review, he also asserted that decentralization was driven by neoliberal economic theory [2]. Delegating authority to sub-national levels would lead to more efficient use of resources, such as material, human resources and financial. Another study by Kristiansen and Pratikno in 2006 stated that LCC as the implementation of decentralization was corroborated by the fact that the leading international agencies also strongly pushed their targets of developing countries, including Indonesia. Therefore, reformation in curriculum needs to be privatized, deregulated and devoluted [3]. Furthermore, they insisted that the government needed to reduce expenditures in public service delivery, including in education.

In brief, Indonesian government urgently needs to act in reformatting the national curriculum by considering the LCC notion. It means it is not only at surface level - as if it changes, but it is just on the cover. It should be carefully designed based on the need of students in one particularly local area and substantially reaching the aim of our education values.

\section{METHODS}

This study utilizes an analytical study approach. This study is based on literature and critical review available in the notion of national versus state curriculum. To answer the problems of 
the review, the content analysis is used to elaborate the phenomenon of what has been written on academic literature on the notion of national and state curriculum.

\section{RESULTS AND DISCUSSION}

The fall of the authoritarian government in 1998 breathed some new air of reform in all sectors of development in Indonesia, including education. The initial reform effort in education touched several issues, such as decentralized education system, school-based management, competencebased curriculum, and local content curriculum (LCC). There was a strong consideration to abolish the nation-wide standardized testing. As a result, national standardized exit examination, in Indonesian language is Ebtanas, for the elementary school was terminated in 2002, and for the secondary education, the number of subjects tested was reduced $^{2}$. Both lower secondary school and upper secondary school only have three subjects for the national exams, compared to the previously five and seven subjects, respectively.

The new form of nation-wide standardized exam was called Ujian Akhir Nasional (National Final Examination), popular with the acronym UAN. The subjects tested were Indonesian language, English, and math [4]. It was up to the schools and provinces to decide whether they required students to take final tests on other subjects.

Based on National Board for Education Standards, the passing grade was 3.01 out of 10.0. As everything was running as expected in 2004 the Ministry of Education decided to raise the minimum threshold for the passing to 4.012. This decision faced strong opposition from many parents and teachers, because they feared it would be too difficult for a great number of students to obtain the minimum of 4.01 for all three subjects. This concern turned out to be the truth. Shocked by the unexpectedly poor results, the Ministry of Education reacted quickly by drawing a conversion table, to many people's surprise, to equalize the achievements of students. Heavily criticized as introducing a great element of gross injustice in scoring, this system had students to answer more than half of the test questions correctly to pass the test [5].

Under the new cabinet in 2005, the new Ministry of Education was still determined to conduct the similar form of tests, which was given a new name, Ujian Nasional (National Examination), shortened as UN. Despite heavy criticisms for the previous UAN, UN still uses the same format, testing three subjects, math, Indonesian language, and English to students at the end of their senior year in middle school and high school. Moreover, UN raises the new minimum threshold, from 4.01 to 4.51, which spread more terror to many of teachers, school principals, and parents, who still have vivid images of what happened in the previous year [6]. Moreover, UN is used as one of the decisive criteria to graduate high school. In short, failure to achieve the minimum threshold in UN will automatically result in failure to graduate high school, regardless the student's overall performance during their school years. As a result, the stakes of the tests have been raised very highly, growing deep concerns of many schools, teachers, and students.

Having the burdened of the national exam to be passed, schools are given other policies to be implemented. On the agenda of devolving authority to local levels, government launched the Local Content Curriculum (LCC) on elementary school to high school curriculum. This policy required twenty percent of total instructional hours to be locally designed in the elementary to upper secondary schools' curriculum ${ }^{5}$. The LCC was stressed in its function as linker between curricula and local content. Ministry of Education and Culture (MOEC) admitted that previous national curricula did not sufficiently consider the diversity of Indonesia [2]. By implementing LCC, MOEC expects that the local realities are exposed in curriculum. For example, students in Bali will get more tourism curriculum, while; students in Java will get more agriculture lesson.

Considering the highly centralized, top-down nature of Indonesian government, the Local Content Curriculum (LCC) program represented a significant departure from previous education policy in Indonesia not only in terms of curricular content but also in the roles and responsibilities assigned to educators ${ }^{5}$. Schools would not implement a standard curriculum constructed entirely by a team of experts in Jakarta. In addition, the MOEC encouraged teachers to experiment with innovative pedagogies designed to brighten up the instruction. Finally, LCC documents identified strategies for managing the new program that foster more democratic authority structures and expand the circle of actors involved in decision-making.

On the contrary, the decision of the current government administration to raise the stake of the national exit examination has raised criticisms, to call it as "re-centralization policy". Moreover, the requirement of passing the national exam to graduate has caused a lot of problems for many students, teachers, and school administrators.

These two approaches, local content curriculum and national exit exam have been viewed as two contrast policies on the same exact time of educational reforms. One encourages the decentralization spirit, and another one is the uniform test that is conducted with the same standard in rural or in urban area, the test that considered even more re-centralized on the system.

Oakes and Lipton argue that these current standardized tests use the same assumptions and procedures as the IQ test design. Tests are designed, administered, and scored in the same fashion. Test-takers are assumed to take tests under the same condition [7]. They oppose the notion that the standardized achievement tests effectively measure how well students master certain knowledge and skills taught in schools [7]. Furthermore, they also point out the culturally bias of standardized testing [7]. Different cultures have different areas of strengths that are emphasized. Some value memorizations, some value personal and social responsibility. Also, poverty 
and oppressive social conditions may influence the test-takers in the standardized tests.

When a standardized test is used as the tool to determine students' academic future, it can be considered as high-stakes testing. Janesick [8] explains that the term 'high-stakes testing' refers to the test "for which the consequences of a student's score are extremely serious". She argues that the high-stakes testing would harm low-income and minority students because funding would be taken away from the poor-scoring schools [8]. Moreover, listing schools as failing schools based on the high stakes testing results would give an impact to the students, who might consider themselves as failing students as well.

In addition to that point, Apple argues that a national curriculum and especially a national testing program are the first and most essential steps toward increased marketization [9]. The national testing provides the mechanisms for comparative data that "consumers" need to make markets work as markets, like the neoliberal's market [10].

Having said that, despite the assumption that marketization is able to increase competition thus enhancing schools' effectiveness, it can at the same time challenge cultural and social inequalities. He believes that marketization has encouraged reproduction of traditional hierarchies of race and class [9]. Firstly, it approves students with 'able' qualities to meet the demand of local competition. Students with special needs were considered to cost more funding and deflated test score [11]. Secondly, it created a discrepancy between the haves and the haves not. This goes with Bourdieu's theory claiming that some students might be wrapped on more cultural capital necessarily for succeeding than the others [12]. Lastly, the measurement of school reforms success might rely only to standardized achievement test, which is attached to curriculum. This subverts the concept of 'success' as a contribution of the whole participants of schools ranging from teachers, students, administrators, community members, local activists and so on [9]. In addition to these points, these propositions are radical transformations that are pastoral based and empirically weak [9]. Apple also argued that overall, all these educational reforms aim to provide compulsory educational conditions that can meet international competitiveness, increase profit and discipline thus able to portray an 'ideal' home, family, and school [10].

In Indonesian context, the ideas of standardized testing to meet international competitiveness were proposed by the former Vice President, Jusuf Kalla, who endorsed the reform in national testing. He believes that the national exams will motivate all elements in education to improve the quality of Indonesian education and improve the international competitiveness of Indonesian students [13]. He also believed in the importance of standards and uniformity of education system. The Minister of Education, Bambang Sudibyo, accused the students who failed the national exams as being lazy [14].

What is more, the Indonesian national testing has also been used as the criteria to decide student graduation. In 2005, 30\% or 400,000 out 1.9 million senior and vocational school students failed the national exam [15]. Some high schools even had $0 \%$ passing rate. Unlike the failing students in 2005, the ones in 2006 were not given the chance for a remedial test. Despite the number decreased significantly to less than $10 \%$, these students were only allowed to take the equivalency test, called Ujian Persamaan Paket C [15]. If they pass, they can get a high school diploma, which unfortunately holds a lower status than the regular one. Students are usually not able to use this diploma for further education. With the current format, the national exam will do a lot more problematic issues to the secondary education life in Indonesia. The only parties that benefit from it are the government's top policymakers who have a sense of accomplishment with the improved test scores, and the tutoring institutions who will get the financial benefit from the stress suffered by students, teachers, and administrators.

The teachers and school administrators have no choice but to comply and deal with the current format of national examination. They have been reportedly very stressed with the pressure of making their students reach at least the required minimum threshold for all the exams ${ }^{3}$. Teachers are forced to sacrifice their creative, innovative, meaningful, and engaging lessons to allow time for students to practice the test drills. School administrators must reallocate resources to meet the test-driven demands, even by partnering with external tutoring institutions to help the students obtain the skills needed to pass the test. Furthermore, Darling-Hammond pointed out that the multiple-choice tests of de-contextualized bits of information could not capture the "minimum skills needed for employment and future education in order to graduate" [16]. Moreover, she emphasizes, "...the use of tests as a sole determinant of graduation imposes heavy personal and societal costs, without obvious social benefits [16]."

Although, neo liberalists devolved more power to school level as influenced by decentralization system, as it combined to neo conservative policies, school principal's power is restricted. In Indonesia, this dilemma is viewed by local content curriculum, where central government is delegating more authority to school level in one side. However, in another side, principals also gradually perform a centrally prescribed curriculum that indicates diminishing power and righteous control over curriculum $[17,18]$. At the same time teachers do not experience the increasing of autonomy but tend to develop intensification. Both have caused principals and teachers burdened with more workloads to meet accountability's demand, and more emotional and physical strain resulted from never-ending schedule of meetings $[9,11,18]$.

On the implementation of local content curriculum (LCC), LCC is viewed as an ambitious reform from top-level decision makers regarding solve the problems of education systems [5]. The problem solving, to keep students continue their education to junior secondary school, is included in three goals of LCC [2]. First, by implementing the LCC, Indonesian government hoped that this program would convince students to continue their school. When the Ministry of Education (MOEC) decided to close all vocational junior secondary schools in 1998. The 
option for schooling was decreasing because people had more concerned in employment rather than intellectual development [2]. Therefore, by imposing the LCC, government hoped that LCC could prevent the students to drop out before graduation of junior secondary school. This could happen because one of the subject areas of LCC is vocational skill. For example, LCC included an agricultural curriculum in planting Salak pondoh, a typical fruit in Yogyakarta [19].

Second, the LCC emphasized on the importance of delegating the authority of design and new curriculum implementation into school level. As the consequence, classroom teachers are suddenly burdened with the responsibility that they have never had before. Last, the LCC was stressed in its function as linker between curricula and local content. MOEC admit that previous national curricula did not sufficiently consider the diversity of Indonesia. By implementing LCC, MOEC expects that the local realities are exposed in curriculum. However, to make it easier for teacher in designing curriculum, most of the schools only consider local language lesson as local content curriculum. Another option, in the provinces that have majority strong believer, schools consider more religious lesson as local content. For example, more Islamic studies in Acehnese schools and more Hindu lessons for Balinese students.

Kristiansen and Pratikno stated that LCC, as one of the aspects in Indonesian educational decentralization policy can be viewed as a fundamental to the development of democracy [3]. They pointed out that this policy, if implemented effectively, could be resulted in increasing participation by ordinary citizens and can be functioned for enhancing interest in public policy [3]. Thus, the accountability of the decision makers could be strengthened in the eye of common citizens [20].

However, in some cases, the urgency of decentralization was driven by neoliberal economic theory [2]. He asserted that delegating authority to sub-national levels would lead to more efficient use of resources, such as material, human resources and financial. This idea was corroborated by the fact that the leading international agencies like the World Bank and The International Monetary Fund (IMF) also strongly pushed their targets of developing countries, including Indonesia, for reformation of privatization deregulation and devolution [3]. They asserted that the decentralization was urged by decentralization because government needed to reduce expenditures in public service delivery, including education. By imposing the decentralization, government delegating the responsibilities, including funding, from central government to district authorities [3]. Not only in line with the aim of affectivity, the idea of decentralization also can be polished in line with the aim in improving education quality.

From an administrative point of view, Breton pointed out that by bringing decision makers closer to the people whom they serve should increase the efficiency and the opportunity for popular monitoring and control [21]. However, the empirical findings do not always show the association between technical efficiency and the practice of decentralization [22]. He added that there is a common tendency that decentralization of authority without a clear allocation of separate responsibilities can reduces the quality and efficiency of public service. In Local Content Curriculum (LCC) case, some problems are identified due the inconsistencies of central government aim with the lower-level implementation.

What is more, the mismatch between central government expectations and local implementation could be effect on static progress in all levels of education system [2]. On his ethnography studies, Bjork found that teacher in Indonesia put their little interest in using their authorities in their schools, the introduction of LCC did not show a delegation of authority from central to local levels. When offered the LCC, they keep expecting and waiting for their supervisors to instruct them on how to implement their work in new setting reform.

The evidence of this non-dynamic progress was come from some findings in the study that show advisory group meeting was not doing actively. This group is responsible for monitoring the implementation of LCC. As one of teacher explained in Bjork's interview "Don't be surprised if you meet our members and they aren't doing anything. In 1997 and 1998 we met only once a year. Now we are waiting for instructions for another meeting. We haven't been given permission yet [2]." In most cases he found that some course titles got some alteration due to LCC reform, but the substance of what students doing remained constant. One of the teachers admitted that they continue to use the curricular and instructional methods they had before LCC, only the titles and the classification of subject that got some alteration following the LCC framework [2]. In Indonesian context, this problem could be happened because the autonomous teacher in a decentralized educational system required more effort and more time investment, which will not increase teachers' salary, so that teachers have a very low interest in implementing the policies. In addition, teachers are still defined as civil servants who are paid and evaluated with old setting by the central government. Therefore, when the new setting requires them to do more effort, they are still comfortable in the behaviours that served them well in the past.

In addition, the funding of LCC is still in grey area [19]. The central government has delegated the implementation of LCC to local authorities. It means no clear budget allocation has funded to each school. As the consequence, the local initiatives should be emerged. Some of students bought their own materials for agricultural class, while teacher should find the ways to provide them the facilities in executing the curricula.

Other difficulties in implementing LCC come from the lack of assistance and supervision from central government to provincial level [2]. The interviews and observations indicated the insufficient assistance in implementation procedure. As the consequence, the teachers who relied on developing curricula often must introduce the lesson without sufficient preparation. The teachers who attended the training complained that the 
training is not answering the real challenges they faced as LCC instructors [2]. Based on these findings, possibly MOEC did not provide the sufficient assistance to smoothen the transfer authority to lower-level institutions.

\section{CONCLUSION}

One of the significant findings to conclude from this essay is that the intention of opening the democracy opportunity to lower-level institutions by imposing the Local Curriculum Content could not be used effectively if the government of Indonesia does not support the implementation holistically. Gaps between central government expectations with teachers' will do existed. In one side, teachers are demanded to be creative in designing local content curriculum, as the symbol of devolving authorities to local school. In contrast, teachers are also forced to sacrifice their creative, innovative, meaningful, and engaging lessons to allow time for students to practice the test drills for national exam preparation. School administrators must reallocate resources to meet the test-driven demands, even by partnering with external tutoring institutions to help the students obtain the skills needed to pass the test. The national exit examination has caused some seriously damaging impacts to the secondary education in Indonesia. Students, even the brightest ones, feel fearful that they will jeopardize their future by scoring one point less than the required minimum threshold in any given exams. The huge gap between the needed capacity and the actual capability of schools to meet the demands of the national exit examination has resulted in serious psychological distress. The government should reconsider for determining students' graduation based on national standardized testing. Furthermore, the lack of action by local actors either in LCC and national exam context is caused by the socio-political context that has traditionally explicated teachers as dutiful civil servants and only functions as the machine of authority. Additionally, when people have been given a democracy as the replacement of past authoritarian system, the clear guideline, sufficient training, and support system from government should be established properly. Otherwise, this participative decision-making or compulsory site-based management viewed as forced collaboration, in the end such mandates simply recreate a new version of top-down, hierarchical leadership. Then, when the decentralization apparently will bring the neoliberalism implicitly in practice, then may be people will urge for another democracy.

\section{REFERENCES}

[1] Ministry of Education (MOEC), Education development in Indonesia: A country report. Jakarta: MOEC, 1996.
[2] C. Bjork, "Decentralisation in education, institutional culture and teacher autonomy in Indonesia," International review Education, vol. 50, no. (3/4), pp. 245-262, 2004.

[3] S. Kristiansen and P. Pratikno, "Decentralising education in Indonesia," International Journal of Educational Development, vol. 26, no. 5, pp. 513-313, 2006.

[4] Badan Standar Nasional Pendidikan (National Board for Education Standards), Peraturan Menteri Pendidikan Nasional Republik Indonesia nomor 34 tahun 2007 tentang ujian nasional SMP/MTs/SMPLB, SMA/MA/SMALB, dan SMK tahun pelajaran 2007/2008, 2007.

[5] The Jakarta Post, Final exams testing time for students, govt. The Jakarta Post [Online]. Retrieved from: http://www.thejakartapost.com/detailweekly.asp?fileid=20070418.@02, 2007.

[6] J. Jidi, Bila nilai UN tinggi, puaskah kita? [Online]. Retrieved from http://www.kompas.com/kompas-cetak/0704/27/jatim/65722.htm, 2007.

[7] J. Oakes and M. Lipton, Teaching to change the world (3rd ed.). Boston: McGraw-Hill, 2007

[8] V.J. Janesick, The assessment debate: A reference handbook. Santa Barbara, CA: ABC-CLIO, 2001

[9] M.W. Apple, "Creating difference: Neo-liberalism, neo-conservatism and the politics of educational reform," Educational Policy, vol. 18, no. 1, pp. 12-44, 2004.

[10] M.W. Apple, Cultural politics and education. New York: Teachers College Press, 1996

[11] D. Gillborn and D. Youdell, Rationing education. Philadelphia: Open University Press, 2000.

[12] P. Bourdieu, Distinction. Cambridge, MA: Harvard University Press, 1984.

[13] Kompas, Standardisasi mutu lewat ujian nasional [Quality standardization by national exam]. Kompas [Online]. Retrieved from: http://www.kompas.com/kompas-cetak/0502/05/opini/1541677.htm, 2005

[14] Kompas, Depdiknas pembunuh [Online]. Retrieved from:http://www.kompas.co.id/metro/news/0606/21/082032.htm, 2006.

[15] Sampoerna Foundation, Increasing the impact and the effectiveness of foundation and donor funding [Online]. Retrieved from: http://www.ifc.org/ifcext/che.nsf/AttachmentsByTitle/Ed_06_Frankel/\$ FILE/Frankel Sampoerna+Foundation Risk+Sharing+Structure.pdf, 2006

[16] L. Darling-Hammond, "Performance-based assessment and educational equity," Harvard Educational Review, vol. 64, no. 1, pp. 5-30, 1994.

[17] S. Gewirtz, The managerial school. New York: Routledge, 2002.

[18] G. Whitty, S. Power and D. Halpin, Devolution and choice in education. Philadelphia: Open University Press, 1998

[19] J. Suprihatiningrum, "The Development of Local Content-Based Science Curriculum for Madrasah Tsanawiyah (Islamic Middle School) in Yogyakarta, Indonesia," IAMURE International Journal of Education, vol. 2, no. 1, pp. 254-265, 2012.

[20] H. Blair, "Participation and accountability at the periphery: Democratic local governance in six countries," World Development, vol. 28, no. 1 , pp. 21-39, 2000.

[21] A. Breton, Competitive Governments: An Economic Theory of Politics and Public Finance. New York: Cambridge University Press, 1996.

[22] D. Treisman, Decentralization and the quality of government. Los Angeles: Department of Political Science, University of California, 2000 